Article

\title{
Technological De-Worlding, Search for a Fleshy Method: An Investigation into La Quotidienne
}

\section{Gerald A. Powell}

\begin{abstract}
The evolution and survival of humankind from the Homohabillis to the Homo-faber would not be so if it were not for technology. We are technological beings and cannot be otherwise, so it is only natural that we are seduced by the orgasmic, rhythmic current of technology. I first explore the idolatry and euphoric metaphysical entanglements associated with technological determinism but also consider if there is reason to throw caution to the wind. Realizing the benefit of technology, Martin Heidegger (The Question Concerning Technology) et al., were optimistically cautious about technological enframing that (de-)worlds humankind from his habitat (fleshiness of being-in-the-world). Resolved to find a solution, Heidegger's project was to avoid Cartesian pitfalls and metaphysical jargon by clarifying Dasein's relationship to transcendence, reinstituting Dasein concretely in the world. Bemused, Heidegger himself said this project remains a puzzlement. This essay considers Henri Lefebvre's Métaphilosophie (Métaphilosophie: Promolegomenas) (Festival, Rhythmnalysis, La Quotidenne, Moments) as a non-philosophical means to dèpasser our technological commonplace and re-habiter the "total man" in the world. What I am proposing here is that if Heidegger's Faustian-like bargain is correct, then Lefebvre's method and possibly others of the same spirit are critical to first locate and account for moments of alienation in one's everyday commonplace and to find or create concrete ways of making do by realizing the potentiality of those moments.
\end{abstract}

Keywords: Lefebvre, rhythmanalysis, La Quotidien, poesis 


\section{In the Beginning: Technology Giveth ...}

$\mathrm{P}$

lato's Phaedrus captures the aura of technophobia in an exchange

between Thamus and Thoth:

Most ingenious Thoth ... this invention [writing] will produce forgetfulness in the souls of those who learn to use it. They will not need to exercise their memories, being able to rely on what is written, calling things to mind no longer from within themselves by their own unaided powers, but under stimulus of external marks that are alien to themselves. So it's not a recipe for memory, but for reminding, that you have discovered. ${ }^{1}$

Plato argued that the written word is a technological mediation that will produce forgetfulness. Among other factors, it cannot defend itself; though convenient, it is mute, lifeless, unresponsive, and is not a way of recalling but reminding. One can advance a similar criticism in that the shift from orality to literacy and on to electronic takes into consideration the aforementioned problems but additionally a host of new technologicallymediated problems of space, time, and indetermination as new mediation often complicates and further distances us from the original source. Gleaned from the two examples is technological mediation but also a human biophilic contract and ethos central to the human condition. Built into any co-present human communicative model is an unstated communicative ethos that does not necessarily exist with digital communication-material presences; therefore, I can't simply delete you, log off, or unfriend you. It's more complicated than that. The same is true with my relation to and with the world. If I'm bored or discontent, I can't simply swap realities with URL addresses and applications. It doesn't work like that. Marshall McLuhan, then Neil Postman, observed humankind's escalating infatuation with technology, how it's being domesticated/wired/circuited into our being. McLuhan argued, in Understanding Media: The Extensions of Man' ${ }^{2}$, that technology isn't just a tool humans use to facilitate their everyday ongoings; it is an artificial extension of their facticity that radically alters their ecology. Postman's Amusing Ourselves to Death ${ }^{3}$ adds to McLuhan's unrealized vision of

1 Plato, Phaedrus, trans. by W.C. Hembold and W.G. Rabinowitz (New York: Macmillan, 1956), 68.

${ }^{2}$ Cf. Marshall McLuhan, Understanding Media: The Extensions of Man (Cambridge, MA: The MIT Press, 1994).

${ }^{3}$ Neil Postman, Amusing Ourselves to Death: Public Discourse in the Age of Show Business (New York: Penguin, 1986).

(c) 2015 Gerald A. Powell

http://www.kritike.org/journal/issue 17/powell december2015.pdf

ISSN 1908-7330

(cc) BY-NC-ND 


\section{AN INVESTIGATION INTO LA QUOTIDIENNE}

Frankenstein as he questions the spatial presence of human consciousness in the digital age. It's quite clear when we communicate in the flesh that our being present does not depend on such things as digital pixilation or highdefinition fidelity. I can reach out, touch you, smell you, and feel your presence, an entirely different fleshy proposition when I Skype, viber, tweet, bank, and shop online. Paul Virilio ${ }^{4}$ realized Postman's Faustian bargain in techno-science, a science of extremes, as a result of reckless epistemological accidents in which we defer "analogue mental process, in favor of instrumental, digital procedures, which are capable, we are told, of boosting knowledge." 5

Regardless of the SPAM panic campaigns set in motion by some "futurist," technology has already been an important bioinformatic gene in the evolution and progression of the human species. Rooted in the earliest myth and sacred literature is transhumanist aspiration, the desire to alter mind and body via technology in order to improve one's life's station, which has always been humankind's desire and naturally part of his evolutionary destiny. Postmansaid, "Every [technology] is the [technology] of a stage of media development [and with it carries a more extreme form of Truth]." 6 I would add human (de)evolution, too, which is the central proposition I would like to consider. Our passivity and knee-jerk response to technology is precarious - a can't-lose, magic bullet attitude trumping rationality and common sensibility should jostle us from our lull and give reason for pause and critical review. But for now, these three archeological threads assist in our limited understanding of the complexity that is our unsettled relationship with and to technology:

1. The surrendering of fleshy organic experiences of being-in-the-world to technological processes

2. The concern for ways in which the media and the body (bio-media) (re)biologizes the body and become circuited into everyday practices of society

3. How remediation of new technology epistemically reorientates the user

Much of the previously mentioned technophobic literature captures the anxiety and the mood of our trepidation, but not the loci of such things. It is my contention that the source of our anxiety is best understood through

\footnotetext{
${ }^{4}$ Cf. Paul Virilio, The Information Bomb (New York: Verso, 2006).

${ }^{5}$ Ibid., 3

${ }^{6}$ Postman, Amusing Ourselves to Death, 24.
} 
the work of M. Heidegger, particularly his treatment of Dasein vis-á-vis technology as enframing the body, and later Henri Lefebvre's exhaustive work on la quotidienne. Before delving into Heidegger, Goethe's Faust and the boiling frog syndrome (BFS) are excellent allegorical primers for understanding Man's entanglements with technology.

\section{Faust, Boiling Frog Syndrome, and Heidegger}

When man sells his soul to technology, what is he really selling, wagering, and relinquishing, and is this worth retrieving? What do we mean by this - as if something urgent and of great value was to slip away, only to find that it is too late to be reclaimed? Seller's remorse? Is our fate similar to Goethe's Faust and his dealings with Mephistopheles-knowledge of ' $X$ ' for the service/bondage of Dasein?

Kurzweil's theatrical account of humanity captures the spirit of Faust and the BFS:

Boiling Frog: A Post-Script

GEORGE2048: I'll be devoted to you in any event. But I can be more than your transcendent servant.

MOLLY2004: Actually, [your] being "just" my transcendent servant doesn't sound so bad.

C. DARWIN: If I may interrupt, it occurred to me that once machine intelligence is greater than human intelligence, it should be in a position to design its own next generation.

MOLLY2004: That doesn't sound so unusual. Machines are used to design machines today.

C. DARWIN: Yes, but in 2004 they're still guided by human designers. Once machines are operating at human levels, well, then it kind of closes the loop. 


\title{
122 AN INVESTIGATION INTO LA QUOTIDIENNE
}

\author{
NED LUDD: And humans would be out of the loop \\ C. DARWIN: $\quad$... So the machines will design their \\ own next generation quickly.
}

GEORGE2048: Indeed, in 2048, that is certainly the case. $^{7}$

Kurzweil's theatrical brings to mind an old witch tale about boiling a frog alive, which goes like this. If you put a frog in a pot of water, slowly increasing the temperature, the frog will not be aware of the temperature change, eventually being boiled alive. While the scientific premise is invalid, the idea is that if one's perception goes unchecked, one is susceptible to any danger that befalls. Technomorphism is an allegory about the BFS as it speaks to technological gradualism, how Dasein unwittingly becomes enframed by technology. Alarming as it sounds, machines/nonbiological intelligence are not only among us but are also a significant part of our ability to go about our day-to-day. Dishwashers, vacuum cleaners, spectacles, vehicles, probes, and medicinals are so much a part of our everydayness that without them we feel dismembered. For the better part of our existence, in order to survive, human civilization has been technomorphic, characterized by gradual technological developments to compensate for human limitations. ${ }^{8}$ Technology not only is a ubiquitous part of our everydayness but also has a naturalness about it so much so that it is understood as a part of our facticity (material informatics) and biology (bioinformatics). We have all but become technomorphic. The more we adapt to these technologies, the more they adapt to us and the more we become strangers to our bodies. Human minds and bodies are essentially open to episodes of deep and transformative restructuring in which new equipment (both mental and physical) can be incorporated into the thinking and acting systems that we have identified as mind and body. For example, when we talk about RAM or a computer performing poorly, human-related terms such as triage, memory, speed, or virus are commonly used to communicate the computer's ability to think, respond, or showcase consciousness. This is to say, references to aperture, battery life, and beach ball, for instance - non-human qualities - become linguistic, interchangeable references with human qualities such as vision, energy/life, and

\footnotetext{
${ }^{7}$ Raymond Kurzweil, Singularity is Near: When Humans Transcend Biology (New York: Viking, 2005), 38-41.

${ }^{8}$ Cf. Heather Cristina Lum, Are We Becoming Cyborgs? How Technomorphism Influences Our Perceptions of the World Around Us (Ph.D. Dissertation, Orlando Florida: University of Central Florida, 2009).

(c) 2015 Gerald A. Powell http://www.kritike.org/journal/issue 17/powell december2015.pdf ISSN 1908-7330
}

(cc) BY-NC-ND 
thinking/consciousness. By extension, smart phones, computers, tablets, and body gear (e.g., Google Glass, RFID chips, Samsung Galaxy, Apple watches) are mechanical versions of our extended limbs; our genetic codes have already been hacked, digitally transcribed, erased, edited, and manipulated. Once carbon, we are also fleshy metal. Technology co-evolves with us. Machines are fundamentally in sync with our biorhythms, everyday patterns, and idiosyncrasies; they know our bodies and sociological tendencies better than we do. With each evolutionary transition, the body and mind become more integrated, structurally complex, and technologically and sociologically enmeshed. A simple technology such as a contact lens with regular use cognitively becomes an extension of one's eye; the same is true with a hammer being an extension of one's hand. We have already become in some respects trans-human as these devices, after years of usage, have become natural extensions and/or accessories of our own body. Now the question is not whether man can transcend his facticity but how he chooses to do so. He is free to transcend himself and in doing so explore possibilities.

Within biomedia, the biological body is not hybridized with machines ... nor is it supplanted by machines [rather] the "intersection between genetic and 'computer' codes facilitat[es] a qualitatively different notion of the biological body-one that is technically enhanced but still fully biological ... a particular instance in which the 'bio' is transformatively mediated by 'tech' so that the bio reemerges more fully biological. ${ }^{9}$

Collectively, my interpretation of Goethe's Faustian bargain, Kerzweil's dramatist (although I am aware he is a proponent of transhumanist technology, his dramatist here is apropos), and the BFS are cautionary signs about what seems to be already a fait accompli concerning humankind's blind fervor toward technology and intelligence that is often passed over as conspiracy or overly deterministic. Kurzweil explained:

The rate of paradigm shift (technological innovation) is accelerating, right now doubling every decade. The power (price, performance, speed, capacity, and bandwidth) of information as a technology becomes more cost effective, more resources are deployed toward its advancement, so the rate of exponential growth increases over time .... With both the hardware and software needed to fully emulate human intelligence, we

${ }^{9}$ Eugene Thacker, Biomedia (Minneapolis: University of Minnesota Press, 2004), 5-6. 


\section{AN INVESTIGATION INTO LA QUOTIDIENNE}

can expect computers to pass the Turing test, indicating intelligence indistinguishable from that of biological humans, by the end of the 2020s. ${ }^{10}$

Why throw caution to the wind? We live with our toys, joined at the hip. They know and comfort us, are always there. They are docile, obedient, efficient, and most important, come in all types of flavors and colors. What possible danger does technology represent? After all, technology has contributed appreciably throughout our existence from the Homo-habilis to our current evolutionary station (Homo-faber) and is a primary reason we exist. Nick Bostrom, professor, director of the Future of Humanity Institute, Oxford University, noted:

Evolution created us ... but we don't need to sit back and let things slide; we can take an active part in shaping our future destiny .... We can use evolutionary methods where it suits us, but we can rein in evolution where we see better ways of selecting ... We can substitute directed evolution for natural evolution. ${ }^{11}$

Bostrom's timely observation would certainly awaken Heidegger's post-mortem slumber on a number of accounts: Dasein's destining toward death $^{12}$, the threat to Dasein's presence being-in-the-world, etc. My concern is antithetical: technological Dasein and how that impacts my being-in-theworld. Heidegger had much to say about the dislocation of Dasein, enframed by technology, whereby Dasein becomes de-worlded, losing touch with the fleshiness of being-in-the-world. When technology wrestles away Dasein from its everyday possibility, then Dasein loses purpose, stands in reserve, losing all relation and drive to a world that is ready-at-hand (Zuhandenheit). Heidegger's hermeneutic regarding technology is too comprehensive to indulge here, including his magnum opus Being and Time ${ }^{13}$, The Question Concerning Technology ${ }^{14}$, and What is a Thing, a lecture given in 1971. However, we can approach Heidegger sensibly, taking a parsimonious approach when evaluating and re-representing his thoughts in relation to my overall objectives. Briefly I revisit Heidegger's treatment of technology vis-à-

\footnotetext{
${ }^{10}$ Kurzweil, Singularity is Near, 35-38.

${ }^{11}$ Nick Bostrom, The Future of Human Evolution (manuscript in preparation), 3.

12 Jesse Bailey, "Enframing the Flesh: Heidegger, Transhumanis, and the Body as 'Standing Reserve,'” in Journal of Evolution \& Technology, 24 (2014): 44-62.

${ }^{13}$ Cf. Martin Heidegger, Being and Time, trans. Joan Stsambaugh (Albany: University of New York Press, 1996). Hereafter referred to as BT.

${ }^{14}$ Cf. Martin Heidegger, The Question Concerning Technology (New York: Harper Row, 1977). Hereafter referred to as TQCT.

(c) 2015 Gerald A. Powell

http://www.kritike.org/journal/issue 17/powell december2015.pdf

ISSN 1908-7330
}

(cc) BY-NC-ND 
vis Dasein being-in-the-world and its influence on Henri Lefebvre's project in which the total-man is grounded or reinstituted in the world. (1) To start, I incorporate Heidegger's BT and TQCT to make clear how enframing threatens man being-in-the-world whereby he is de-worlded and loses the fleshiness of experiences. Since Dasein always seeks itself, it always wants to become what it is. (2) Heidegger's vision of Dasein fails due to its Cartesianism; it does, however, create space for refinement where Henri Lefebvre's reinterpretation of the Greek term poiesis highlights the ready-athand potential in the La quotidien (rhythm, moments) whereby the total man is made total by his concrete efforts of making do, rupturing the Cartesian duality, and allowing for the reinstitution of being vis-à-vis festival. Key in my usage of the festival is its aesthetic and sociological significance, not economical, political, or (a)historical. Lefebvre is quite clear that the purpose of the festival was to transform how life is understood and lived, advocating for a new style of living. The festival beckoned the proletariat to wake from his slumber: "Seul l'action du prolétariat au cours d'une critique efficace (pratique et théorique) de sociéte existante permet des les faire enter dans la vie et de réaliser la vérité sociale." The only action for the proletariat is to effectively critique (merger of theory and practice) society's existence, life realized, and the true life. Festivals, particularly the Parisian commune, gave pause for the proletariat to take action and were a transformative moment to transcend the Homo-faber en route to the Homo-quotidien..$^{15}$ The commune was more than a work/labor dispute or political hats jockeying for power. It was the proletariat's declaration of life and his fortitude to recapture $\mathrm{La}$ quotidien from contradictions, the limits of bourgeois society ${ }^{16}$ and negation of those things that prohibit and enframe "the total man" from emerging 17 whereby he remains a stranger to himself.

\section{Heidegger: Dasein and Enframing}

Heidegger's term enframing is useful here in that (1) it underscores technology not only as an instrument that humans create, make, produce, or as something external to us, but also as an ontological frame that humans make intelligible the world and categorize how the world is revealed to them. Specifically, enframing serves as a Cartesian way of relating to ourselves and others within-the-world, thereby dislocating Dasein as being-in-the-world, whereby it loses all familiarity, occluding it from taking up a fundamental relationship with the world. (2) The telos of technology here is not a thing or

\footnotetext{
${ }^{15}$ Henri Lefebvre, Proclamation De La Commune (Paris: Gallimard, 1965), 26-27.

${ }^{16} \mathrm{Ibid}$., 28.

${ }^{17}$ Ibid., 390-391.
} 


\section{AN INVESTIGATION INTO LA QUOTIDIENNE}

an end for itself; it is that whichever distances Dasein from being within-theworld, its history, the unfurling of its being toward destining and possibility.

The threat to man does not come in the first instance from the potentially lethal machines and apparatus of technology .... The rule of enframing threatens man with the possibility that it could be denied to him to enter into a more original revealing and hence to experience the call of a more primal truth. ${ }^{18}$

Regarding our current epoch, the implications of Heidegger's observation are unsettling. With every technological adaptation, something essential about humanity or human activity is abandoned, lost, or standing in reserve. The body is muted, numbed to its own facticity, loses its memory to its environment (Umwelt) and "otherness." In its natural state, Dasein seeks itself in relation to being-with-others in the world in which it discloses with their being a fundamental point of being-with that is altogether transformed into mechanistic gestures. It is my concern that technology is usurping our fundamental attunement with being-in-the-world, "falling prey" in Heidegger's words, where ordinary experiences appear strange; those everyday organic activities that constitute being-within-the-world are ever widening, creating an epistemological and ontological breach and in the process choking the growth of Dasein. What is lost by enframing is the "fleshiness of experience," the essence of man whereby he wrestles with the world: orders it, domesticates it according to epistemological superstitions the more the world resists, the stronger his chokehold. To a fault, man projects his expectations onto a thorny, indifferent world that is silent to his request. And so it is through the tensions of the flesh that enframing brings man into a faux existence with and to the world. Whether we understand "fleshiness of experience" via Sartre's lamentation of man being a series of projects/plans; Camus's Sisyphus; St. Augustine's confession; Unamuno's meditation, ${ }^{19}$ The Tragic Sense of Life; Dasein's being-with (Mitsein); or Maurice Merleau-Ponty's phenomenology of kinaesthetics - the fleshiness of being human is a thorny, lived-bodily experience. "The thickness of the body, far from rivaling that of the world, is on the contrary the sole means I have to go unto the heart of things, by making myself a world and by making them flesh." 20

${ }^{18}$ Heidegger, TQCT, 14

${ }^{19}$ Miguel de Unamuno, The Tragic Sense of Life (New York: Dover, 1954).

${ }^{20}$ Maurice Merleau-Ponty, The Visible and the Invisible: Studies in Phenomenology and Existential Philosophy (Evanston, IL: Northwestern University Press, 1969), 135.

(c) 2015 Gerald A. Powell

http://www.kritike.org/journal/issue 17/powell december2015.pdf

ISSN 1908-7330

(c) ) BY-NC-ND 
So the problem presented before us is clearer. If we are enframed or practice the art of enframing, standing in reserve as Heidegger suggests, how does technology impact our being-with-the-world, being-in-the-world; what is being concealed that otherwise would be revealed? Enframing presents Dasein with several problems alluded to in passing. For instance, technology serves as the essential de-facto reference to the world and those things that constitute the world. A more fundamental problem is Dasein's eigentlichkeit (authenticity and/or ownedness in terms of possession) and the provocation that technologies pose. Technology de-worlds Dasein, which means: (1) it reclaims the everyday from Dasein in the sense of ownedness, (2) it fractures and commodifies Dasein, inhibiting its ability to relate, share, and take care. These are primary ontological and existential structures of Dasein in which Dasein is (authentic) eigentlichkeit; La quotidien, therefore, is a mosaic of everyday fleshy experiences (body + subject $=$ fleshy) resuscitating Dasein, bringing Dasein to eigentlichkeit. By its nature, Dasein is characterized as possibility, not in terms of "this or that" but existentially, pushing toward, being more.

Dasein is also never less. It is existentially that which is not yet in its potentiality of being. And only because the being there gets its constitution through understanding and its character of project, only because it is what it becomes or does not become, can it say understandingly to itself: become what you are! ${ }^{21}$

(3) Our task, then, is both an existential and phenomenological one in which Dasein is brought into authenticity, a movement away from merely seeing to knowing, that is to move from present-at-hand (Vorhandenheit) to ready-to-hand (Zuhandenheit) in order to gain access into the thickness of everyday.

\section{Heidegger: Dasein, Spatiality, and De-Worlding}

In BT and TQCT Heidegger characterizes Dasein as an indeterminate journeying through the ontological corridors of everydayness, using its instruments to bring-forth, blossom, or unconceal. The assumption here is that technology brings about a spatiality (nearness, closeness, indeterminate). In terms of spatial proximity, Mejias noted, "Technology bridges distances; however, it does not bridge 'the existential gap between the knower and the known'.... In fact, the whole experience might result in an increased feeling of alienation from the object and from the 'real' world ..."22 Alienation here

${ }^{21}$ Heidegger, BT, 146.

22 Ulises A. Mejias, “Movable Distance: Technology, Nearness and Farness," in Ulises A. Mejias, <http://blog.ulisesmejias.com/2005/01/20/movable-distance-technology-nearness-andfarness>, 15 August 2014.

(c) 2015 Gerald A. Powell

http://www.kritike.org/journal/issue 17/powell december2015.pdf

ISSN 1908-7330 


\section{AN INVESTIGATION INTO LA QUOTIDIENNE}

is a result of a world that has been altogether enframed and mediated through signs and referents, that which is Vorhandenenheit (present at hand) and does not go beyond. Common logic suggests that mediated technologies bring us to a more intimate knowledge of the world; paradoxically, for Dasein an instrumental mediated world only distances no matter how penetrating the instrument. Instrumentation only de-worlds Dasein, drives Dasein away from the light into the shadows from all those things that are natural.

In terms of one's fleshy existence, we can say that when one is deworlded one is phenomenologically amputated from their ecological niche, body, everyday ongoings, and interactions that constitute their everydayness. Movements, gestures, and any semblance of authenticity are reduced to predictable links of cookied probabilities and algorithms. By a click of the Function key, the world waits at our command. Why participate, engage in the everydayness of things, when we can move it with a mouse, watch it or edit it-a dash of color here, hi-fidelity sound in the comforts of our commonplace; after all, there is nothing more to wish for, see, discover, or be; the world is past tense. Intelligent technologies not only thwart the art of living-experience of moment and presence-but allow for spacetranscending movements and sensory experiences that derail its users from being fully present within physical space. "A [user] does not end with the limits of his physical body or with the area to which his physical activity is immediately confined but embraces, rather, the totality of meaningful effects which emanates from him temporally and spatially." ${ }^{23}$ Users are fluid-able to speed up, slow down, skip, repeat, pause, reboot, download, upload, connect, and disconnect at their own discretion. At the center of users and their technological Dasein is the reality that "users" are not only quantum superpositions but can mash up space, conjoining digital space with physical space. Second, these user-friendly technologies - "I," "you," "my," and body sensory technologies - allow for a user's being to absorb and be absorbed. Ironically, each spatial pronoun/metaphor further takes into consideration how users are epistemologically and ontologically distanced and eventually de-worlded into an orgasmic abyss of mirrors and self-gratifying echoes.

"Our love affair with [technology] ... runs deeper than aesthetic fascination and deeper than the play of the senses. We are searching for a home for the mind and heart." 24 With SIRI and translator in hand, we saunter down the yellow brick road committed to the never-ending search for our being. The aforementioned scenario emphasizes how enframing unearths and spaces man from his natural biophilic state as zoon politicion while

\footnotetext{
${ }^{23}$ George Simmel, "Metropolis and Mental Life," in The Blackwell City Reader, ed. by G. Bridge and S. Watson (Malden, MA: Blackwell Publishing, 2002), 17.

${ }^{24}$ Michael Heim, The Metaphysics of Virtual Reality (New York: Oxford University Press, 1993), 85 .

(c) 2015 Gerald A. Powell

http://www.kritike.org/journal/issue 17/powell december2015.pdf

ISSN 1908-7330
}

(c) $\mathrm{BY}-\mathrm{NC}-\mathrm{ND}$ 
driving away every possibility of authenticity to shadow. If not de-worlded, what is revealed that otherwise is concealed, and how is humankind drawn from the shadow into the light? What is required to pursue this investigation is not another Cartesian experiment but a métaphilosophie of La vie vecu, not as an anthropologist with his tools but as a being ready to wrestle with the world at hand and in wrestling discovering possibilities of being-in-theworld. La quotidien is a type of intimacy - a phenomenology of the flesh that can assist in the reinstitution of Dasein being-in-the-world.

\section{Heidegger's Alltäglichkeit and Lefebvre's La Quotidien: Prelude to a Method}

L'homme ... est à la fois enfoncé dans
La quotidien et privé de quotidien.
(Man is ... at once submerged in
the everyday and deprived of it.) - Blanchot $^{25}$

Heidegger sees everydayness (Alltäglichkeit) in terms of averageness in which we encounter the other in terms of their facticity; whether their presence serves as wallpaper to our ongoings or their idle chat the background noise to a chain of meaningless exchanges: Good morning, paper or plastic, credit or debit, sugar with that, and what does SIRI have to say are all inauthentic and become the mode of expectation by which we encounter others and the world. For Heidegger, the aforementioned descriptions signify a world that has become all too familiar with no possibility, stripped down, depersonalized, and filled with waiting rooms with no chairs. In such a world there is no sense of transzendens because every possibility is outside of that which is possible.

My treatment of the La quotidien establishes Heidegger's Altäkleishkeit as a fundamental backdrop for everydayness insofar as it signifies averageness, ennui, and a sense of anxiety about one's being-in-theworld in which Dasein is stuck in a sea of existential meaninglessness (cycles, repetitions, constancy antithetical-movements, and impossibilities). For Heidegger there seems to be little to no konkret existence for Dasein beingin-the-world, which Heidegger duly noted ${ }^{26}$ in his lecture "On the Essence of Ground"27, letters to Jasper, Bultmann, and his ongoings with Husserl, mainly due to perceived metaphysical pitfalls. Heidegger's project, which is

\footnotetext{
${ }^{25}$ Maurice Blanchot, La parole quotidienne (Paris: Gallimard, 1962), 356.

${ }^{26} \mathrm{Cf}$. Heidegger, $B T$.

${ }^{27}$ Cf. Martin Heidegger, On the Essence of Ground, trans. by William McNeil (UK: Cambridge University, 1976).
} 


\section{AN INVESTIGATION INTO LA QUOTIDIENNE}

too exhaustive to account here, was to clarify Dasein's relationship to transzendens in the manner that being is revealed. Heidegger noted in "On the Essence of Ground," transzendens is equated to surpassing, constitutes self-hood, something that belongs uniquely to Dasein (Dasein in itself as transzendens), Dasein as surpassing, exceeding, and grounded in truth in the manner in which Dasein achieves authenticity. Heidegger could not truly escape Cartesian metaphysics and his efforts remained inconclusive but paved space for Lefebvre's critique of philosophy and application of métaphilosophie. Heidegger's influence on Lefebvre is often passed over, but it should be noted that Heidegger was the twentieth-century philosopher with whom Lefebvre conversed the most. ${ }^{28}$ (I will return to this point.) For the purposes of our query here, Heidegger was one of the earliest modern philosophers to foresee the inherent dangers in overvaluing technology and some preliminary solutions to restore Dasein. To that, Lefebvre argued that everyday life has been colonized by new technology-work-labour and needs to be reorientated to its elemental sensibilities. ${ }^{29}$

The link between Dasein and authenticity, which by Heidegger's measure still remains philosophically inconclusive, may not have been all for naught because it inspired H. Lefebvre's appropriation of Marx's alienation and the reconstruction of the Greek term poiesis to mean harnessing the creative potential existing in nature to human activity: "Poiesis thus [becomes the] creation of works (oeuvres) [in which man in his depraved state transforms his alienation and makes do]." ${ }^{30}$ This is similar to Michel de Certeau's perruque, a mid-level, cog in the wheel employee whose total being-way of identifying with the world-is strapped to the mechanistic cycle of his oppressive place of business. He is nothing more than his mechanistic mandates but by making do, in Lefebvre's terms (poiesis), finds ways of transcending, re-inventing himself, and relating to the world on his own terms. In "Notes Written One Sunday in the French Countryside," Lefebvre journaled a pedantic account of how festivals heal wounds from alienated labor, mend old friendships while establishing new ones, form community, and inspire harmony between man and nature by rebirthing humankind to his natural state.

Poesis and festivals were not only restorative but seeded elements (the necessary creative energy) that sprouted moments of revolution. ${ }^{31}$ To reinstitute humankind into the world, one must transform one's being-in-the-

\footnotetext{
${ }^{28}$ Cf. Stuart Elden, Understanding Henri Lefebvre: Theory and the Possible (New York: Continuum, 2004).

${ }^{29} \mathrm{Ibid}$., 76-77.

${ }^{30}$ Henri Lefebvre, Métaphilosophie: Promolegomenas (Paris: Gallimad, 1965), 26.

${ }^{31}$ Gavin Grindon, "Revolutionary Romanticism: Henri Lefebvre's Revolution-asFestival," in Third Text, 27:2 (March 2013), 208.

(c) 2015 Gerald A. Powell

http://www.kritike.org/journal/issue 17/powell december2015.pdf

ISSN 1908-7330
}

(c) $)$ BY-NC-ND 
world, how one dwells and practices, and one's disposition to and with the world, being mindful that festival-if it is to have any meaning beyond metaphysics - must lead to revolution: a style of living. No matter how ephemeral, moments were opportunities in which humankind could live and achieve their potential: "No aspect of himself, of his energy, his instinct, was left unused. Perhaps he was basic and elementary, but at least he lived without being fundamentally 'repressed' ..."32 He continued to say that moments "must be capable of opening a window on supersession, and of demonstrating how we may resolve the age-old conflict between the everyday tragedy, and between triviality and Festival." ${ }^{33}$ Lefebvre turned to Marx's writings on the 1871 Parisian commune; later he was critical of its lack of inspiration and creativity, but nonetheless it was necessary for him to develop his treatise, The Meaning of the Commune, in which he establishes an aesthetic ground on which the worker/laborer overcomes alienation by creatively working through and is fundamentally remade into the total man. This is to say the Commune was more than a political statement against the state; it was festival as revolution in that it underscored (1) moments of negation as a first step to creativity, (2) the aesthetic (speech act, poeisis, poetry, creative demonstration) as a fundamental component of social movements, (3) everything that alienated man from the aesthetic: work, labor, technology, etc. - it was about how to live, the manner of living, the style of living, and by the practical means, and (4) how to re-establish, trust, order, and the social contract that once existed between humankind and their environment.

Sketches of revolution as festivals are outlined in the Critique of Everyday Life, Volumes 1 (1991) and 2 (2008), Métaphilosophie, and Rhythmanalysis (2004) as it was a restorative project with scattered philosophical vestiges soldered to create Lefebvre's Métaphilosophie. Lefebvre took on Heidegger's project from a materialist objective framework. He reworked it with Marx (alienation and praxis), Hegel (objective idealism), insights from Guy Debord's Situationist International (SI; revolutionary movement), Andre Brechton's Surrealism (radical ethnography and artistic projects), and Gaston Bachelard (elements and moments), subjecting it to a radical transformation in which abstraction and materialism produced a concrete truth based on practical, historical, and social reality. (I should add there are vestiges of Sartre involved that Lefebvre could not avoid, although he tried.) Lefebvre's method is not overly romantic, but it is grounded in the everyday mood, tone, moment, and rhythm of the lived life that inspired the SI and others to utilize art as a weapon within social movements. Ultimately

${ }^{32}$ Henri Lefebvre, Critique of Everyday Life, Vol. 1 (New York: Verso, 1991), 207.

${ }^{33}$ Lefebvre, Critique of Everyday Life, Vol. 2 (New York: Verso, 2008), 358. 


\section{AN INVESTIGATION INTO LA QUOTIDIENNE}

Lefebvre reconciled various methods and philosophical positions in his Métaphilosophie.

\section{Search for a Method: Mètaphilosophie and Quotidienne}

"Suggesting that in order to understand the world [Lefebvre noted] we cannot base it on individual conscience [Sartre] ... nor can we simply understand it on the basis of praxis, the Marxist misconception." 34 Central to Lefebvre's position is that (1) we must abandon philosophy for the investigation of praxis, as philosophy tends to be too speculative, uninspiring, and appreciably ontological and (2) Lefebvre's metaphysics, particularly Heidegger's ontology regarding Dasein was still too abstract and offers no reprieve. Lefebvre sees La quotidienne as the true mètaphilosophie as a radical way to dépasser rather than tranzend. Recognizing the totality and complexity of the human subject as a sociological, historical, and biographical being involved in creative processes of making do in his common place, Lefebvre's quotidienne (emphasizes the "total man," rather than Dasein) stresses finding meaning in the ordinary, routine, rhythms, cycles, repetition, signs, mètro-boulot-dodo, production, reproduction, objects, space, and diversions that alienate and de-world man from his habitat. "Notes Written One Sunday in the French Countryside" in the Critique of Everyday, Volume 1, followed by his exposition of Theory of Moments in Volume 2, offer a glimpse of Lefebvre's thinking as he realized the potential of his mètaphilosophie (moments, ceremonies, praxis, and festivals/revolution). To say what moments are proves quite difficult as Lefebvre alludes to them by style, a type and or formation of poises. The only concrete thing we can say about a moment is that it is seeded in indetermination: absolute, impossible possibility of ambiguity that becomes existentially purposeful in that it transforms the everyday through revolution. What I am particularly interested in is bringing clarity to a dimension of moments, those existential attributes, elements, and stages of existence leading toward a referendum on style of living.

[Existential] moment comprises a totality that can illuminate, however briefly, new possibilities for social relations and cultural practices along with new opportunities to realize them. Lefebvre's theory of moments could [bottle] a revolutionary upsurge or a

${ }^{34}$ Elden, Understanding Henri Lefebore, 78.

(c) 2015 Gerald A. Powell

http://www.kritike.org/journal/issue 17/powell december2015.pdf

ISSN 1908-7330

(c) BY-NC-ND 
flash of cultural innovation [and unleash it in creative reforming ways]. ${ }^{35}$

Significant here is Moore's use of the celestial and astronomical metaphors illuminate, flash, and the quantum metaphor of possibility, which is complementary to Lefebvre's metaphoric verbiage of constellation, astrological, spirituality, spontaneity, etc. Thematically these adjectival metaphors depict the religious and almost transformative nature of the moment. Similar to Saul's transformation to Apostle Paul, Christ's lament on the cross - "It is finished" and Lefebvre's revelation as he walks through the pyrenees - "the moment is an attempt to achieve the total realization of a possibility." 36 Continuing with our astronomical references, moments (gravitational, weak, electromagnetic, and strong) were forces necessary for the birth of the universe and everything that followed including everyday life. "Everyday life is the native soil in which the moment germinates and takes root." 37 Predicting the birth of a star, let alone cosmic pregnancy, is indeterminate and at best speculative. The same holds true for moments. Moments are always present and indeterminate, predicting the how and when these moments take form is at best existential.$^{38}$ The moment is always empty/full in the sense that nothing visible has yet to happen, but as we have discussed it is full in the sense that its necessary elements, although dormant to the eye, are always churning; thus, determining when the moment ruptures everyday life is the game of everydayness in which the Dionysian (festival) and the Apollonian (tragedy) contest.

Certainly, right from the start, festivals contrasted violently with everyday life, but they were not separate from it. They were like everyday life, but more intense; and the moments of that life-the practical community, food, the relation with nature-in other words, workwere reunited, amplified, magnified in the festival. ${ }^{39}$

Festivals were sacred spaces where people could not only renew their kinship to friends, family, and community but also challenge the current institutionalized paradigm and move toward possibilities - potentialitiesimagination, wresting the everyday from the inertia of rationalism.

${ }^{35}$ Ryan Moore, "The Beat of the City: Lefebvre and Rhythmanalysis," in Situations, 5:1 (2013), 69.

${ }^{36}$ Henri Lefebvre, Critique of Everyday Life (New York: Verso, 2014), 642.

${ }^{37}$ Ibid., 651.

${ }^{38} \mathrm{Ibid}$., 63.

${ }^{39}$ Lefebvre, Critique of Everyday Life, Vol. 1, 207. 


\section{AN INVESTIGATION INTO LA QUOTIDIENNE}

Lefebvre's method is that which seeks to locate and account for moments as transformative possibilities in one's everydayness, and finding practical ways to dèpasser alienation by realizing the potentiality of those moments. Moments provoke spatial situations and the possibility for man to take action-to restructure one's being from those commodifying forces that seek to shackle the human spirit, making the most out of those situations. In doing so, birthing conditions for the total man emerge. This is not to say that the total man spontaneously combusts at a final stage in man's historical evolution; he is "a figure on a distant horizon beyond our present vision ... a limit, an idea and not a historical fact". ${ }^{40} \mathrm{He}$ is part of a continuous revolutionary praxis - both individual and collective-which aims to reform everydayness by taking ownership and responsibility of one's style of living. We can say that the métaphilosopher utilizing Lefebvre's Métaphilosophie is concerned with everyday practices, specifically the metaphoric prowess of poiesis, how space is performed and utilized, and how moments prod situations in which the "total man" can emerge and realize. The métaphilosopher also assumes the role of an autoethnographer-not divorced from that which he is observing. He attends to his fleshiness, uncertainties, obfuscation, and blurred experiences. He absorbs his alienation, finds potentialities in those moments of making do (mixed genre, storytelling-i.e., performance, fiction, evocative techniques, speech acts, drama, all renderings to hail attention to normal subversive everyday practices that fracture society-that go unchecked and seem organic) producing situations and ways to dèpasser. Diagramming these observations, we can say the métaphilosopher is tuned with those embryonic debris that birth cosmic shape and frequencies of life: rhythmic cycles of everydayness (i.e., biological, physiological, metaphysical, anthropological, material, structural) by means of difference, repetition, and frequency. "Everywhere where there is interaction between a place, a time, and expenditure of energy, there is rhythm." ${ }^{41}$ To say that the mètaphilosopher is a cartographer of rhythms for revolutionary purposes is not an overstatement; he charts, graphs, highlights, scales, and measures everydayness in order to diagram the creative potential of living.

In the future the art of living will become a genuine art .... The art of living presupposes that the human being sees his own life-the development and intensification of his life - not as a means towards 'another' end, but as

\footnotetext{
${ }^{40}$ Lefebvre, Critique of Everyday Life (2014), 88.

${ }^{41}$ Henri Lefebvre, Rhythmanalysis (New York: Continuum, 2004), 15.
} 
an end in itself .... The art of living implies the end of alienation - and will contribute towards it. ${ }^{42}$

\section{Rhythmology}

1. To begin, one must assume the role of a rhythmologist. A rhythmologist is fundamentally attuned to the tones and textures of everydayness. (See point 3.) This is similar to the mythologist who is not only doing the mythologizing but is part of the myth.

2. Supposing there is a centre at which the method begins, one might begin with the lamentation: Is this my life, and what has become of it? Any query into the quotidienne assumes a strangeness or absurdity that splinters the individual's commonplace and feeling of revolution, not just on behalf of one's self but on behalf of humanity which inspires an art of living - "to change the world, we must change life." 43

3. Quotidienne or quotidienettè is comprised of physical and metaphysical structures, strategies, tactics, things, codified systems, games, rules, and forms that are ordinary, repetitive, and homogenic that strip life from any modicum of authenticity. The reformation of quotidiennettè sheds light on those structures that appear to be mired in sameness and exposes them for their differences and potentialities vis-à-vis repetitive difference $(1+1+1 \ldots){ }^{44}$

4. The rhythmologist must be able to identify an ensemble of varying rhythms, repetitions, temporalities, and spontaneous actions (calendrical, bodily, lunar, mechanical, geographical) as they are interwoven into the lifecycle of everydayness that account for a critical part of how we arrange and order movement within space and time. Raymond Queneau's Exercises De Style is a rapport of everydayness in which repetition is used to probe the limitations of linguistic wordplay, newness,

\footnotetext{
${ }^{42}$ Lefebvre, Critique of Everyday Life, Vol. 1, 199.

${ }^{43}$ Elden, Understanding Henri Lefebvre, 118.

${ }^{44}$ Lefebvre, Rhythmanalysis, 6.
} 


\section{AN INVESTIGATION INTO LA QUOTIDIENNE}

banality, style, and sensation. And Georges Perec's Tentative d'épuisement d'un lieu parisien is a visual sketch of rhythms, norms, cycles, timetables, movements of mobility, habitations, and connections over a 3-day period in which these accounts are reported through café windows. ${ }^{45}$

5. The rhythmologist must be able to engage idealism with praxis and poises. Michel De Certeau's la perruque is "[t]asked with defusing or 'making do,' the mapless minefield of his place of employment ... without promise of a transparent user manual, camouflages his vexation by encoding his ways of operating vis-à-vis aesthetic performance [as a way of revolting against the established order].

6. Counter rhythms include English graffiti artist Banksy, various splinters of Occupy, Networked movements (Arab Spring), and Indignados. These examples of aesthetic revolutionary rhythmic tactics of resistance echo Lefebvre's festival as revolution. What is hoped for by employing a method of rhythm to La quotidienette is the rediscovery of a style of living-moments that reaffirm man's natural order in the universe and in doing so reinstitute the total man.

What are we signifying when we say that we are reinstituting the total man, rescuing him from alienation (e.g., technology, work, labor)? Are we saying that there is more to being-in-the-world than the mechanical pulley, leverage, cable rhythms of the métro boulot dodo-that there is a style of life that is worth fighting for? That technology divorces man from beingin-the-world, denatures him from work, community, others, and self? Yes! But we are not disillusioned, drunk in absolution or mysticism. We are affirming that alienation and ennui are not the final stage of human growth and evolution but a necessary stage for man in his effort to become what he is - the total man - and that this concept of the total man, which may merely be symbolic, does not deter man from exceptionality. Equally, it does not preclude that man is a cycle of repetitive failed projects that lull him into a purgatory of non-expectation that steals away moments of authenticity - new

45 Cf. Georges Perec, Tentative d'epuisement d'un lieu parisien (France: Christian

(c) 2015 Gerald A. Powell

http://www.kritike.org/journal/issue 17/powell december2015.pdf

ISSN 1908-7330

(cc) BY-NC-ND 
ways of thinking, seeing, and being. The total man is more than the sum of its parts; it is the quantum particles of everyday that go unnoticed that have the potential to transform the rhythms of everyday and in doing so impact moments, situations, and culture. Acts, gestures, performances, and creative expressions are exercises of potentialities evidenced in the works of Charles Baudelaire's Flâneur; Edward Hopper's "Gas" and "Hotel Room," François Truffaut's Bertrand in L'Homme qui aimait les femmes (1993), Luce Giard, Georges Perec, Maurice Blanchot, Roland Barthes, et al., all of whom have contributed appreciably to the reinstitution of being via La quotidien. Their works collectively describe a certain fleshy phenomenology that reinstates humankind into a world of possibility. At the core of La quotidien is indetermination, an openness/hazy-cloudiness, an unfurling of temporal possibility - the stretching along of what is to be the total man. Resuscitating the total man, breathing new life into his lungs, are those ordinate objects, sensations that give shape to everydayness (e.g., the fleeting scent of a beautiful passerby, the smell of newness after a summer rain, the sea of humanity pouring into the crevice of the underground, the undulating throb and pitch of sound gyrating at Delhi's AIIMS, a random shredded tire in the middle of the highway, or the misrecognition of a hand wave from a beautiful woman that pulsates the heart). These sensations can ignite what Stéphane Mallarmé noted, "la vie, immédiate, chère et multiple, la nôtre avec ses riens sérieux" (life, immediate, clear and multiple, with our own serious nothings). ${ }^{46}$ Everydayness is not entrenched inside us or enframed somewhere else, it is all around us so we must manually pursue our investigation with the fleshiness of our senses, bringing ourselves into an authentic relationship with the world situation by situation and in doing so creating spatial possibilities for reinstitution of the total man.

\section{Reinstitution of The Total Man}

Appropriation versus alienation and spaces of between(ness) mark our current crisis.

Reinstitution of the total man is tantamount to pursuing the everydayness with openness and newness-thus, matter, objects, experiences, sensations, no matter how ordinary they appear, are sociological potentialities (Zuhandenheit). At the center of appropriation is authenticity in which man relinquishes his shackles and finds his style of living. "Ce qui compte n'est pas seulment ce que les forces sociales font de notre vie quotidienne mais ce que nous faisons de ces forces à travers notre mainére de

${ }^{46}$ Stéphane Mallarmé, Oeuvres completes (Paris: Gallimard-Pléiade, 1945), 718.

(c) 2015 Gerald A. Powell

http://www.kritike.org/journal/issue 17/powell december2015.pdf

ISSN 1908-7330

(cc) BY-NC-ND 


\section{AN INVESTIGATION INTO LA QUOTIDIENNE}

les vivre" 47 (What counts is not simply what social forces do to our everyday life but what we do with those forces through the way we live them). Declaring his freedom, the total man yells, "I hate everything that merely instructs me without augmenting or directly invigorating my activity." 48 Nietzsche's lament is not anarchic, but it does encourage us to engage in a radical pedagogical undertaking, questioning the fleshy epistemic and ontological grounding to which our senses instruct. So entrenched in the cultural logic of everyday, our senses are without perception. When we see what are we not seeing, and when we hear what are we not hearing? So when we pursue a style of living with all of our flesh, we are seeking a project of negation and consummation, stressing a radical poiesis and purification of our senses. Our eyes are a test to see if we can see beyond them. Aristotleian reasoning and Newtonian mechanics are merely mental exercises-two of many cognitive dimensions or ways we have become familiar strangers. The total man is not a mystic figure whose purpose is messianic; his life is an intense project-a supernova for others to see. He is exemplary of what is possible when one transcends cultural logic and sensibility. "Sadly, the stars of what is possible shine only at night .... Until such time as mankind has transformed this light and this darkness, stars will shine only at night." ${ }^{49}$ And until such a time, Lefebvre notes, we must revolt.

I am reminded of the Yippies' 1968 "Festival of Light" in which LSD was dropped into the NYC water supply, fuck-ins were staged, etc. All questioned the cultural logic of the time, raising issue and association with the concept of pleasure insofar that it's permissible under the auspice of consumerism. Mediated through theater, play, and festival, the Yippies included the everyday passerby and lingering materials for props. It was not a members-only movement; it depended on community involvement. ${ }^{50}$ Similar to Lefebvre, the Yippies' protest reinforced the importance of solidarity, collective consciousness, carnival, and community building. Other festive revolutionary examples include:

1. Boulevard de Bonne-Nouvelle, described in Breton and Eluard's Immaculate Conception-the everyday is what is and what appears only if we could apprehend it. In practice, the boulevard is

\footnotetext{
${ }^{47}$ Lefebvre, Métaphilosophie: Promolegomenas, 349.

${ }^{48}$ Cf. Friedrich Nietzsche, "On the Utility and Liability of History for Life," in Untimely Meditations, trans. by R.J. Hollingdale and ed. by Daniel Breazeale (Massachusetts, Cambridge University Press, 1983).

${ }^{49}$ Lefebvre, Critique of Everyday Life (2014), 642.

${ }^{50}$ Cf. Benjamin Shepard, Play, Creativity, and Social Movements: If I Can't Dance, It's Not My Revolution (New York: Routledge, 2013).

(c) 2015 Gerald A. Powell

http://www.kritike.org/journal/issue 17/powell december2015.pdf

ISSN 1908-7330
}

(c) ) BY-NC-ND 
synonymous with potential energy, formless space, space that has yet to be articulated or practicedindeed banal without expectation.

2. Recently, Chinese Flash Mob Tuangou united, where consumers connect on social media, agree to purchase from a specific vendor, and demand a reduced rate. ${ }^{51}$

3. 5 Points in NYC

4. Pop-up classes at The New School in which random lectures across NYC would surface. Pop-up classes challenged the role of the university as an economic extension of government and private interest whose primary interest was vested in a system of perpetual training and indentured servitude.

5. The Reverend Billy and the Church of Stop Shopping 52 is an anti-consumer film and movement that stages flashmob and street theatric performances in consumer-driven spaces. The movement inspires more than just an intellectual awareness of neoliberal capitalism and herd mentality; it provokes awareness of how one can get out there and do something, individually and as a community.

These projects have several things in common: they reinstitute the subject as an active agent who (in)habiter space. The verb "habiter" provides a grounding, making it possible for the subject to chart uncharted geographies or corriger géographies anciennes (correct old geographies) and create new ones. Second, the subject is consubstantiated with his projecttheir life is an experience, translated in French as experiment, a mélange of projects that brings one to attention. Third, each project dépassait, paraphrasing Feurbachian's reformation: How can we change the world,

${ }^{51}$ Joel Backaler, "Tuangou: Chinese Consumers Group Together for Bargains," in The China Observer (30 December 2008), < http://thechinaobserver.com/2008/12/30/tuangou-chineseconsumers-group-together-for-bargains $>, 16$ August 2015.

52 The Reverend Billy and the Church of Stop Shopping, directed by Lucia Palacious and Dietmar Post (New York: Play Loud! Productions, 2002). 


\section{AN INVESTIGATION INTO LA QUOTIDIENNE}

rather than merely interpret it. ${ }^{53}$ It brings grounding to the Cartesian chasm by bridging two distinct worlds - that which man perceives (historical) and that which he imagines (reverie). Said in another way, the total man is not just simply a linear historical entity, homo eretcus, destining toward a factical end; he's a homo quotidien, fluid, rhizomatic, whose very presence ruptures any premeditated destining. The total man is a man of the moment. "The moment offers us a taste or a glimpse of unity and connection, and although it is temporary ... it has the power to change the course of history and the quality of everyday life." 54

In closing, with every technological concession gained, it is only responsible to ask what is in jeopardy of being lost, and if lost, is it worth retrieving? Technological development is speeding up, parceling, fragmenting, and distancing man from his natural state. The trick is to see technology as a red herring. Whether or not I possess the latest mediated something is to miss the point. The issue set forth is one of technological enframing and its implications toward man being-in-the-world. Staying faithful to the ongoing rhythmic course, man's end is a de-worlded one as light is eclipsed by the eternal shadow - fait accompli, or does man revel in the light-eclipsed shadow until the darkness draws its final chill upon his being. Accepting the second proposition that the everyday is worth fighting for is the recognition of the lived experience (habiter + expérience = La vecu), indeterminate moments between the light and darkness, transitions of existence at the level of daily life that beckon humankind to realize their potential, a humanity grounded not so much in the quantity of social interactions, processes, inputs and outputs, places, and things but in the quality of those social fusions, con(fusions), and the richness of relationships and experiences fostered. I'm not convinced that my individual effort here will inspire a change in how we approach, befriend, and engage technology or La quotidienne. On a very concrete level, I hope it can illuminate feelings of unease and discomfort, giving reason to question the very elements of our everydayness, to hail attention to how unfamiliar (artificial-minced-flat white-homogenous) the world has become, what we have become, and what we can do to peel away the silicon and metal veneer enveloping our everydayness to recapture the fleshy moment of being human.

School of Media Studies, The New School University, United States

\footnotetext{
${ }^{3}$ Cf. Frederick Engels and Karl Marx, Ludwig Feuerbach and the End of Classical German Philosophy (Peking: Foreign Language Press, 1976).

${ }^{54}$ Moore, "The Beat of the City," 69.

(c) 2015 Gerald A. Powell

http://www.kritike.org/journal/issue 17/powell december2015.pdf

ISSN 1908-7330
}

(c) $)$ BY-NC-ND 


\section{References}

Backaler, Joel, "Tuangou: Chinese Consumers Group Together for Bargains," in The China Observer (30 December 2008), < http://thechinaobserver.com/2008/12/30/tuangou-chineseconsumers-group-together-for-bargains $>, 16$ August 2015.

Bailey, Jesse, "Enframing the Flesh: Heidegger, Transhumanism, and the Body as 'Standing Reserve,'"' in Journal of Evolution \& Technology, 24 (2014).

Blanchot, Maurice, La parole quotidienne (Paris: Gallimard, 1962).

Bostrom, Nick, The Future of Human Evolution (manuscript in preparation).

Elden, Stuard, Understanding Henri Lefebvre: Theory and the Possible (New York: Continuum, 2004).

Engels, Frederick and Karl Marx, Ludwig Feuerbach and the End of Classical German Philosophy (Peking: Foreign Language Press, 1976).

Grindon, Gavin, “Revolutionary Romanticism: Henri Lefebvre's Revolutionas-Festival," in Third Text, 27:2 (2013).

Heidegger, Martin, Being and Time, trans. by Joan Stambaugh (Albany: University of New York Press, 1996).

On the Essence of Ground, trans. by William McNeil (UK: Cambridge University Press, 1976). The Question Concerning Technology (New York: Harper Row, 1977).

Heim, Michael, The Metaphysics of Virtual Reality (New York: Oxford University Press, 1993).

Hopper, Edward, Gas, 1940. Oil on Canvass. Museum of Modern Art, New York.

Hotel Room, 1931. Oil Paint. Thyssen-Bornemisza Collection, Madrid.

Kurzweil, Raymond, Singularity is Near: When Humans Transcend Biology (New York: Viking, 2005).

Lefebvre, Henri, Critique of Everyday Life (New York: Verso, 2014). , Critique of Everyday Life, Vol. 1 (New York: Verso, 1991). , Critique of Everyday Life, Vol. 2 (New York: Verso, 2008). Métaphilosophie: Promolegomenas (Paris: Gallimard, 1965). , Proclamation De La Commune (Paris: Gallimard, 1965). Rhythmanalysis (New York: Continuum, 2004).

L'homme qui aimait les femmes, dir. François Truffaut. Henri Agel, Chantel Balussou, Nell Barbier, Anne Bataille (MGM Warner, 1993).

Lum, Heather Christina, Are We Becoming Superhuman Cyborgs? How Technomorphism Influences Our Perceptions of the World around Us

(c) 2015 Gerald A. Powell http://www.kritike.org/journal/issue 17/powell december2015.pdf ISSN 1908-7330 


\section{AN INVESTIGATION INTO LA QUOTIDIENNE}

(Ph.D. Dissertation, Orlando, Florida: University of Central Florida, 2009).

Mejias, Ulises A., "Movable Distance: Technology, Nearness and Farness," in Ulises A. Mejias, < http://blog.ulisesmejias.com/2005/01/20/movabledistance-technology-nearness-and-farness $>, 15$ August 2014.

Merleau-Ponty, Maurice, The Visible and the Invisible: Studies in Phenomenology and Existential Philosophy (Evanston, IL: Northwestern University Press, 1969).

Moore, Ryan, "The Beat of the City: Lefebvre and Rhythmanalysis," in Situations, 5:1 (2013).

Mallarmé, Stéphane, Oeuvres completes (Paris: Gallimard-Pléiade, 1945).

Nietzsche, Friedrich, "On the Utility and Liability of History for Life," in Untimely Meditations, trans. by R.J. Holingdale, and ed. by Daniel Breazeale (Massachusetts: Cambridge University Press, 1983).

Ong, Walter, Orality and Literacy (New York: Methuen \& Co., Ltd., 1982).

Perec, Geroges, Tentative d'épuisement d'un lieu parisien (France: Christian Bourgois, 1982).

Plato, Phaedrus, trans. by W.C. Hembold and W.G. Rabinowitz (New York: Macmillan, 1956).

Postman, Neil, Amusing Ourselves to Death: Public Discourse in the Age of Show Business (New York: Penguin, 1986).

The Reverend Billy and the Church of Stop Shopping, directed by Lucia Palacios and Dietmar Post (New York: Play Loud! Productions, 2002).

Sheppard, Benjamin, Play, Creativity, and Social Movements: If I Can't Dance, It's Not My Revolution (New York: Routledge, 2013).

Simmel, George, "Metropolis and Mental Life," in The Blackwell City Reader, ed. by G. Bridge and S. Watson (Malden, MA: Blackwell Publishing, 2002).

Thacker, Eugene, Biomedia (Minneapolis: University of Minnesota Press, 2004).

de Unamuno, Miguel The Tragic Sense of Life (New York: Dover, 1954).

Virilio, Paul, The Information Bomb (New York: Verso, 2006).

(c) 2015 Gerald A. Powell

http://www.kritike.org/journal/issue 17/powell december2015.pdf

ISSN 1908-7330

(cc) BY-NC-ND 